\title{
Morpho-physiological and molecular responses of two Libyan bread wheat cultivars to plant growth regulators under salt stress
}

\author{
El Hadi Hadia, ${ }^{1,2}$ Amor Slama, ${ }^{2}$ Leila Romdhane, ${ }^{1}$ Hatem Cheikh M'hamed, ${ }^{1}$ \\ Ahmed Houssein Abodoma, ${ }^{3}$ Mohamed Ali Saed Fahej, ${ }^{4}$ Leila Radhouane ${ }^{1}$ \\ ${ }^{1}$ National Institute of Agronomic Research of Tunisia, University of Carthage, Ariana, Tunisia; ${ }^{2}$ Faculty of \\ Science, University of Carthage, Bizerte, Tunisia; ${ }^{3}$ Department of Genetics, Faculty of Agriculture, \\ University of In Shams, Egypt; ${ }^{4}$ Biology Department, College of Science, University of Elmergib, Khoms, \\ Libya
}

\begin{abstract}
To study the effects of salt stress and plant growth regulators (kinetin, gibberellic acid, potassium) on growth, yield, glycine betaine content, phosphoenolpyruvate carboxylase (PEPC) and ribulose biphosphate carboxylase (RBC) gene expression of two Libyan bread wheat varieties, a factorial design of greenhouse experiment with three replications was conducted. Results revealed that salt stress significantly reduced plant growth and productivity of both varieties. Moreover, the addition of kinetin + potassium and gibberellic acid + potassium had improved the performance of the morpho-metric parameters of both genotypes under salt stress; but the performance was more effective for kinetin treatment than for gibberellic acid. At the biochemical level, the results showed that salt stress increased glycine betaine contents in both varieties with different proportions. This increase is more elevated in the presence of kinetin + potassium than the treatment with gibberellic acid + potassium, which showed an almost similar result as in only salt stress. At the molecular level,
\end{abstract}

Correspondence: Amor Slama, Faculty of Science, University of Carthage, 7021 Jarzouna, Bizerte, Tunisia.

E-mail: slamaamor@yahoo.fr

Key words: Libyan bread wheat; glycine betaine; ribulose biphosphate carboxylase; phosphoenolpyruvate carboxylase; plant growth regulator; salinity.

Acknowledgements: this study was supported by the Plant Physiology Laboratory of National Institute of Agronomic Research of Tunisia, the Agriculture Research Centre in Libya and Keaam station and Agriculture Faculty, Ain shams University, Egypt.

Conflicts of interest: the authors declare no conflicts of interest.

Received for publication: 6 April 2020.

Revision received: 13 August 2020.

Accepted for publication: 14 August 2020.

(C) Copyright: the Author(s), 2020

Licensee PAGEPress, Italy

Italian Journal of Agronomy 2020; 15:1633

doi:10.4081/ija.2020.1633

This article is distributed under the terms of the Creative Commons Attribution Noncommercial License (by-nc 4.0) which permits any noncommercial use, distribution, and reproduction in any medium, provided the original author(s) and source are credited. the effects of salt stress and plant growth regulators on the PEPC and $\mathrm{RBC}$ gene expression showed that the increase was significantly higher for kinetin, gibberellic acid, and salt stress when compared to the control.

\section{Introduction}

Cereals have an important place in food security worldwide, particularly in developed countries (Slama et al., 2018). Such products are on the increase as favourite foods in urban areas (Taylor et al., 2006) and are used for human food, animal feed, and industrial preparations (Nhemachena and Kirsten, 2017). Among wheat species, bread wheat (Triticum aestivum L.) is the most widely cultivated crop around the globe, but the production is far from satisfying an ever-increasing demand (Crespo Herrera et al., 2018). This low production, particularly in developing countries, is attributed to many factors such as the quality of seeds, a low input agronomic practice, and unavailability of varieties adapted to varying climatic conditions. The gap between offer and demand will be more acute under climate change, particularly in arid and semi-arid regions, where water is the main factor limiting production and productivity (Radhouane, 2013).

In Libya, similar to many North African countries, wheat is one of the most important cereal crops. It is a common food for Libyans due to the broad use of wheat flour in the manufacture of bread, pasta, biscuits, and other wheat-related industries. Cultivated areas of wheat in Libya were about 165.000 hectares in 2017 and the quantity produced was about 200.000 tons in 2017 with an average yield of about 1.25 tons/ha (Buba et al., 2017). Causes of the low yield include water scarcity as well as poor and saline soils, among other factors. Alsharhan et al. (2000) documented that approximately $1.900 \mathrm{~km}^{2}$ is affected by salinity, probably due to using seawater for irrigation, poor drainage, and increasing concentrations of salts in the irrigated water from seawater intrusion. In these conditions, wheat and other crops have to cope with daily exposure to hyperosmotic stress (Maggio et al., 2011).

The effects of abiotic stress on agricultural production are well known, reducing not only food production but also, if prolonged, it could potentially upset economic stability (Yadav et al., 2019). Salinity stress has a great impact on the agronomic, physiology, and chemical characteristics of the wheat plant. Generally, salinity affects plant growth in three manners: osmotic stress, ionic stress or ion imbalance, and oxidative stress (Rani et al., 2019).

To adapt to salinity, a plant must develop a plethora of mechanisms, such as osmotic adjustment, to cope with salt stress and to facilitate their metabolic functions (Woodrow et al., 2017). Osmotic adjustment is insured by organic compounds, among oth- 
ers, to resolve these imbalances (Hossain and Dietz, 2016) and to help plants to withstand salt stress (Tian et al., 2017). Among compatible osmolytes, glycine betaine (GB) is one of the most effective osmoprotectants against drought and salinity (Kurepin et al., 2015). It is also implicated in increasing ribulose biphosphate carboxylase (Rubisco) activity under salinity (Wani et al., 2013).

It has also been reported that carboxylate metabolism is modified under salinity to increase the tolerance and resistance to salt (Khan et al., 2014). The phosphoenolpyruvate carboxylase (PEPC) activity, resulting primarily from the ionic stress, was shown to be increased in a salt-treated $\mathrm{C}_{4}$ plant, a $\mathrm{C}_{3}$ plant, and $\mathrm{C}_{3}-\mathrm{C}_{4}$ intermediate plant (Doubnerová and Ryšlavá, 2011).

Bayramov and Guliyev (2014) reported that Brachypodium distachyon leaf contains a greater amount of Rubisco activase small (RCAS) isoform than the Rubisco activase large isoform (RCAL) under optimal growth conditions. Increased levels of the RCAL isoform compared with the RCAS isoform were found in leaves and green stems under salt stress.

Besides natural strategies developed by plants (Suo et al., 2017), several other managements have been deployed to improve plant growth efficiency under salinity. Among them, we can cite the use of hormone regulators or plant growth regulators (PGRs) to create homeostasis in hormonal production under salinity. These phytohormones have been used to ameliorate the adverse effects of salinity stress on plant growth and productivity in various plant species (Nimir et al., 2015). Using potassium nitrate $\left(\mathrm{KNO}_{3}\right)$ for seed-priming treatment showed beneficial effects on plant growth and the production of a wide range of plant species under limited growth conditions (Zanotti et al., 2013). Kinetin (Ki) is a growth regulator that falls under the cytokinins (CK) group, which regulates cell division, apical chloroplast biogenesis, nutrient mobilization, and shoot differentiation (Davies, 2010). Ki was found to be the most effective experimental treatment to improve the salt tolerance, growth, and fruit yield of cucumber genotypes (Gurmani et al., 2018). In fact, seed pre-treatment with kinetin exerted a beneficial effect on seedling emergence, plant growth, and the antioxidant defence system in sweet sorghum (Nimir et al., 2015). Seed pre-treatment with kinetin can minimize the adverse effects of salt stress on germination and subsequent shoot biomass (Nimir et al., 2015).

Gibberellic acid (GA3), as a plant growth regulator, enhances various physiological responses in plants (Rout et al., 2017) such as germination, plant growth, and photosynthetic activity. Exogenous application of GA3 had positive effects on different morphological, physiological, and biochemical activities at salt stress conditions. Gibberellic acid had better mitigation of the harmful salinity effects by increasing vigour, antioxidative enzyme activity, and accumulation of osmolytes (Lambari et al., 2018).

The present study aims to compare and to investigate the effects of two plant growth regulators on some morphological parameters and yield components of an older and a recent Libyan bread wheat (Triticum aestivum L.) varieties to improve their salt stress tolerance. The physiological response (osmotic adjustment) was also studied by measuring glycine betaine (GB). On the molecular level; the effects of the aforementioned treatments on PEPC and RBC gene expression were also estimated.

\section{Materials and methods}

\section{Plant material}

This study was conducted in an agricultural research center in Libya at Keaam station. Two bread wheat varieties (Triticum aes- tivum L.) were used: 'Krassie' and 'Bohoot 210'. 'Krassie' is an autochthonous bread wheat and among the oldest varieties in Libya. It was largely cultivated by southern Libyan farmers in the area of Wadi-Ataba, near the coast. The cultured area of this variety decreased in the early 1970s because the establishment of large agricultural projects using improved varieties leading to modern cultivation and large productivity. 'Krassie' is characterized by its tolerance to high salinity. 'Bohoot 210' is a new variety that was released by the agriculture research center (ARC) in Tripoli, Libya in 2014. It is produced from lines obtained from the international center for the improvement of maize and wheat (CIMMYT). It is characterized by moderate salt tolerance.

\section{Growth conditions}

Plants were cultivated in plastic pots of $30 \mathrm{~cm}$ in diameter filled with sand, and sowing density was adjusted to 10 seeds per pot. The experiment was conducted at the greenhouse of the Research Station under fully controlled conditions at $22 / 25^{\circ} \mathrm{C}$ with a photoperiod of $16 \mathrm{~h}$ light and $8 \mathrm{~h}$ dark and $75 \%$ humidity. Onequarter strength Hoagland solution was added as a source of nutrients for the plants in the sandy culture experiment. The salinity treatments were applied after 30 days from the sowing date whereas the first spraying treatment was applied after 50 days from the sowing date. The second spraying treatment was applied after 70 days at the elongation stage.

\section{Salinity and plant growth regulator treatments}

Pots were arranged for both varieties in three replications. Treatments of salinity and PGR combination were as follows: Control (C, 0 ppm NaCl); Salinity (S, 5000 ppm NaCl); salinity + kinetin + potassium nitrate spray $(\mathrm{S}+\mathrm{Ki}+\mathrm{K}, 5000 \mathrm{ppm} \mathrm{NaCl}+50$ $\mathrm{ppm}$ kinetin $+1500 \mathrm{mg} / \mathrm{L}$ potassium nitrate); and Salinity $+\mathrm{GA} 3$ + potassium nitrate spray $(\mathrm{S}+\mathrm{GA} 3+\mathrm{K}, 5000 \mathrm{ppm} \mathrm{NaCl}+50 \mathrm{ppm}$ $\mathrm{GA} 3+1500 \mathrm{mg} / \mathrm{L}$ potassium nitrate) .

There were four treatments tested in a two-factor (variety and treatment) factorial completely randomized design. The total number of pots assessed was 24 ( 2 varieties $\times 4$ treatments $\times 3$ replications).

\section{Measured parameters}

The effects of the aforementioned treatments on wheat plants growth of the two cultivars were assessed by measuring five different traits at the end of the experiment: shoot dry weight $(\mathrm{g})$, the number of leaves/plant, number of seeds/plant, seeds weight/plant (g) and hundred seeds weight $(\mathrm{g})$.

The variation of each parameter under the three treatments compared with the control was calculated according to the following formula:

$$
\% \text { variation }=100-\left(\frac{\text { treatment }}{\text { control }} \times 100\right)
$$

\section{Glycine betaine extraction and estimation}

Glycine betaine (GB) content was estimated according to the procedure of Bessieres et al. (1999). Plant material was frozen in liquid nitrogen after harvesting then ground to a fine powder. The powder was weighed and transferred to several precooled $1.5 \mathrm{~mL}$ tubes and stored at $-80^{\circ} \mathrm{C}$. Samples of 40 to $50 \mathrm{mg}$ fresh weight were suspended in $1 \mathrm{Ml}$ of MilliQ grade water, subjected to a freeze-thaw cycle by freezing in liquid nitrogen and thawing for 20 min at $40^{\circ} \mathrm{C}$ and left overnight at $4^{\circ} \mathrm{C}$.

Samples ( 2 varieties $\times 4$ treatments $\times 3$ replications) were then centrifuged at $14000 \mathrm{~g}$, at $4^{\circ} \mathrm{C}$ for $5 \mathrm{~min}$, and the clear supernatants separated from the pellets. The fractionation of the crude extract 
was performed using ion-exchange chromatography. Samples were subjected to HPLC analysis, with an HPLC mobile phase of13 mM sodium heptane sulfonate $(2.63 \mathrm{~g} / \mathrm{L})$, and $5 \mathrm{mM} \mathrm{Na}_{2} \mathrm{SO}_{4}$ $(0.71 \mathrm{~g} / \mathrm{L})$ in MilliQ grade water, adjusted to $\mathrm{pH} 3.7$ with $\mathrm{H}_{2} \mathrm{SO}_{4}$ (the solvent was degassed).

The GB amount was determined using HPLC by injecting the extract $(20-100 \mu \mathrm{L})$ onto an ODS2 C18 column $(250 \times 4.6 \mathrm{~mm}$ internal diameter) preceded by a pre-column $(10 \times 1 \mathrm{~mm})$ packed with the same phase. The HPLC mobile phase was delivered by an isocratic pump at a flow rate of $0.8 \mathrm{~mL} / \mathrm{min}$. The complete run lasts 15-20 min. The eluted GB (retention time 4-5 min) was detected by measuring the absorbance at $200 \mathrm{~nm}$ using a spectrophotometer and quantified by a comparison of peak surface areas with those obtained with pure GB standard solutions.

The variation of GB under the three treatments compared with the control was calculated according to the following formula:

$$
\text { Variation of GB content } \mathrm{n} \text { fold } / \text { control }=\frac{\text { treatment }}{\text { control }}
$$

\section{RNA extraction from plant cells and tissues}

Leaf samples of the two wheat cultivars were collected from the treated and control plants for RNA extraction. Total RNA of fresh wheat tissue was extracted using the Gene JET Plant RNA Purification Mini Kit (Thermo Scientific, EU) according to the instructions of the manufacturer. The cDNA was synthesized from the RNA templates using Thermo Scientific Revert Aid First Strand cDNA Synthesis Kit.

\section{Real-time PCR}

Quantitative reverse transcription-PCR (RT-PCR) for the PEPC and RBC genes was conducted. The RNA of 48 samples (2 varieties $\times 4$ treatments $\times 2$ enzymes $\times 3$ replications) was reverse transcribed, to produce the first strand of cDNA in presence of 5 $\mathrm{mM} \mathrm{MgCl}$, 1 X PCR Buffer, $1 \mathrm{mM}$ dNTPs, 25 units MuLV reverse transcriptase and 4 units RNA-guard ribonuclease inhibitor. The mixture was prepared as described above in three different PCR tubes. $2.5 \mu \mathrm{L}$ of $20 \mathrm{pmol}$ of PEPCs reverse primer with the sequence (CTG CAA AAG CCA AAT AAG TC) was added to the mixture in one of the three PCR tubes and the second tube. $2.5 \mu \mathrm{L}$ of 20 pmol of Rubisco (RBC) reverse primer with the sequence (GTA AAA TCA AGT CCA CCR CG) was added in a final reaction volume of $30 \mu \mathrm{Lin}$ each tube. Reactions were carried out at $42^{\circ} \mathrm{C}$ for $30 \mathrm{~min}$, followed by a $10 \mathrm{~min}$ step at $94^{\circ} \mathrm{C}$ to denature the enzyme, then there was a cooling period at $4^{\circ} \mathrm{C}$. To assay the realtime PCR quantification of cDNA encoding for PEPC and RBC, one $\mu 1$ of cDNA of the 48 aforementioned samples was used as templates in the reaction mixtures, in a final volume of $25 \mu \mathrm{L}$ in all assays. Real-time PCR, using PEPC and RBC forward and reverse primers with the following sequences [PEPCs forward (TGT CCA CAA GAA TGC TTC CA), reverse (CTG CAA AAG CCA AAT AAG TC)] and [RBCs forward (ATG TCA CCA CAA ACA GAG ACT AAA GC), reverse (GTA AAA TCA AGT CCA CCR CG)], respectively, were employed to define the detection limit of the assay. Cycling was carried out in a Stratagene Mx-3000 Real-time PCR system which allows the detection of most commercially available dyes including FAM, SYBR ${ }^{\circledR}$ Green I, TET, HEX ${ }^{\mathrm{TM}}$, $\mathrm{JOE}^{\mathrm{TM}}, \mathrm{VIC}^{\mathrm{TM}}, \mathrm{TAMRA}^{\mathrm{TM}}$, Texas Red ${ }^{\mathbb{R}}, \mathrm{ROX}^{\mathrm{TM}}, \mathrm{Cy}^{\mathrm{TM}}, \mathrm{Cy}^{\mathrm{TM}}$, and ALEXA Fluor $^{\circledR} 350$. The system supports 96 -well plate format and can perform multiple sub-experiments up to four dyes in the same well. Bioron product, SYBR ${ }^{\circledR}$ Green I Real-Time QPCR (cat No. $119205)$ master mix for (100 rcs) detection protocol was used in this investigation as described in the Bioron manual.

\section{Quantification of PEPCs, and RBCs gene expression}

The SqRT-PCR quality and concentration were measured by the use of a Quawell Q5000 UV-Vis spectrophotometer (V2.1.4, USA).

The variation of PEPC and RBG gene expression was expressed as follows:

Variation of PEPC and RBC gene expression $\mathrm{n}$ fold/control $=\frac{\text { treatment }}{\text { control }}$

\section{Statistical analysis}

Statistical analysis was performed using SAS 2002 software version 9 (SAS Institute, 1990). The analysis of variance (ANOVA) was performed using the general linear model (GLM) procedure to determine the effect of the treatment (sub-factor) and the effect of the variety (main factor), as well as their interaction. The least significant difference (LSD) test was considered significant at $\mathrm{P}<0.05$.

\section{Results}

\section{Yield components and morpho-physiological parameters}

Salinity led to a reduction of all parameters for both wheat cultivars. Statistical analysis (Table 1) showed that treatment effect was significant for all parameters. The Tukey grouping test (Table 2) indicated that salinity effect was different from others treatments for all traits. The variety effect was also significant for all parameters except for $\mathrm{L} /$ plant $\left(\mathrm{P}=0.4677^{\mathrm{ns}}\right)$. Variety $\times$ treatment interaction was significant only for number of seeds/plant and seeds weight/plant. The response to salt stress without phytohormones varied between cultivars. For Bohoot210, shoot dry weight, seed number and weight per plant were reduced, compared to control (in \%), more than 'Krassie'; whereas the number of leaves and the 100 seeds weight decreased more in 'Krassie' $(-42.9 \% /-33.3 \%$ and $-39.3 \% /-29.5 \%$, respectively) (Table 3 ). Statistical analysis showed that all interactions were significant except 100 seeds weight and number of leaves by plant) (Table 1).

Table 1. Analysis of variance of morphological parameters and yield components at maturity of two bread wheat varieties.

\begin{tabular}{lccc}
\hline Variables & Source of variation & df & P-value \\
$100 \mathrm{SW}$ & Variety & 1 & $<0.0001$ \\
& Treatment & 3 & $<0.0001$ \\
& Variety $\times$ Treatment & 3 & $0.6109^{\mathrm{ns}}$ \\
SW/plant & Variety & 1 & $<0.0001$ \\
& Treatment & 3 & $<0.0001$ \\
& Variety $\times$ Treatment & 3 & 0.0028 \\
\hline $\mathrm{N}^{\circ}$ S/plant & Variety & 1 & $<0.0001$ \\
& Treatment & 3 & $<0.0001$ \\
& Variety $\times$ Treatment & 3 & 0.0005 \\
L/plant & Variety & 1 & $0.4677^{\mathrm{ns}}$ \\
& Treatment & 3 & 0.0009 \\
& Variety $\times$ Treatment & 3 & $0.6500^{\mathrm{ns}}$ \\
\hline SDW & Variety & 1 & $<0.0001$ \\
& Treatment & 3 & $<0.0002$ \\
& Variety $\times$ Treatment & 3 & 0.05 \\
\hline
\end{tabular}

$100 \mathrm{SW}$, hundred seed weight; SW/plant, seed weight/plant; $\mathrm{N}^{\circ} \mathrm{S} /$ plant, number of seeds/plant, L/plant, number of leaves/plant; SDW, shoot dry weight; ns, no significant. Variety: Krassie and Bohoot 210; Treatment: control, salinity, $\mathrm{Ki}+\mathrm{K}+\mathrm{S}$, GA3+K+S. 
The results of the treatment $\times$ varieties interaction are reported in Table 3. Under the control conditions, the 'Bohoot210' variety with a smaller number of seeds had a higher seed weight (100 seed weight) than 'Krassie'. 'Bohoot 210' also had a heavier stem than 'Krassie'. Under spray treatments, plant characteristics with kinetin + potassium + salinity or GA $3+$ potassium + salinity had a lower reduction compared to the salinity treatment (Table 3). Kinetin and GA3 were acting as improvements for plant salt tolerance. Shoot dry weight, seeds weight/plant, and hundred seed weight decreased less in the presence of both phytohormones than without them, whereas in 'Bohoot 210' the no. of leaves per plant were not significantly influenced by kinetin. In the case of the seed number per plant, the response induced by kinetin and AG3 treatments was higher than the control for 'Bohoot 210'. Table 2 showed that kinetin application had values similar to the control for $100 \mathrm{SW}, \mathrm{N}^{\circ} \mathrm{S} /$ plant and L/plant.

The results also revealed that, for both cultivars, the spray treatment with kinetin + potassium improved the plant salt tolerance more than GA3 + Potassium. Treatments with Ki and GA3 showed significant different values for all parameters except $\mathrm{N}^{\circ}$ S/plant and SDW (Table 2).

The glycine betaine contents in the cultivar 'Krassie' increased 2.03 times from the control to the salt-stressed treatment, 3.23 times in the salt-stressed $+\mathrm{ki}+$ potassium treatment, and 2.18 times in the salt-stressed $+\mathrm{GA} 3+$ potassium treatment (Figure 1). For the 'Bohoot 210' variety, glycine betaine contents increased from the control to the salt-stressed treatment by 1.47 times and3.11 and 1.57 times in the salt-stressed, salt-stressed $+\mathrm{ki}+$ potassium and salt-stressed + GA3 + potassium treatments, respectively. Salinity stress and salinity with PGR treatments increased GB contents in the two bread wheat genotypes, but the increment was more important for salt-stressed treatments sprayed with kinetin (3.23 and 3.11-fold). Moreover, the 'Krassie' variety under salt stress only or sprayed with GA3,seemed to accumulate more GB than 'Bohoot 210' (Figure 1).

\section{Gene expression profiling of PEPCs and RBCs}

Gene expression changes of PEPCs and RBCs at the transcription level were estimated under the control and three aforementioned treatments. The results are shown in Figure 2.

The expression pattern analysis in response to salt stress and the two sprayed treatments revealed a significant increase in the expression level of PEPCs. In 'Krassie', salt stress induced 2.07foldexpression levels compared to the control, while the salinity and kinetin + potassium treatment increased expression 3.92-fold, and salinity and GA3 + potassium induced PEPCs expression up to 2.38-fold (Figure 2).

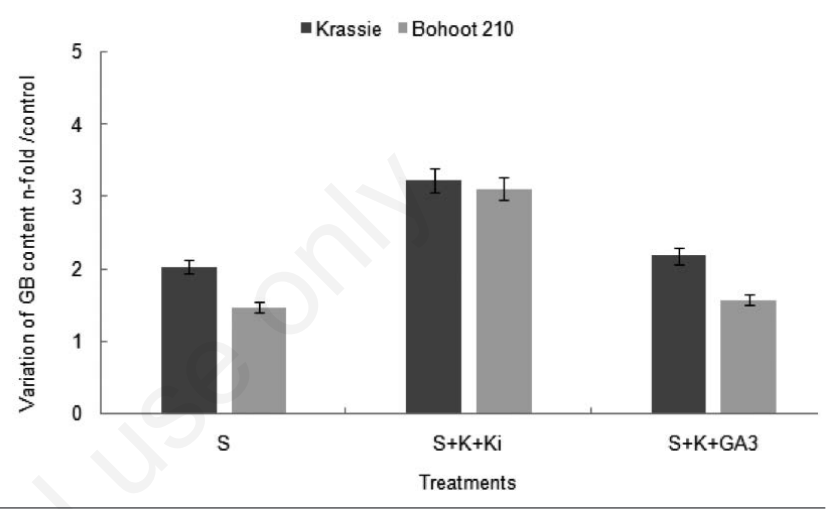

Figure 1. Variation of the glycine betaine content (GB) $n$-fold compared to control under salinity and plant growth regulators of the two bread wheat varieties. $\mathrm{Ki}+\mathrm{K}+\mathrm{S}$, kinetin + potassium nitrate + salinity; $\mathrm{GA} 3+\mathrm{K}+\mathrm{S}$, giberellic acid + potassium nitrate + salinity; S, salinity; Ki, kinetin; $K$, potassium nitrate; GA3, giberellic acid; GB, glycine betaine.

Table 2. Average SW, SW/plant, $N^{\circ}$ S/plant, L/plant and SDW (two-way ANOVA, variety $\times$ treatment) for the two varieties, Krassie and Boboot 210 under the different treatments. Means followed by the same letter are not significantly different according to the Tukey multiple range test $(\mathbf{P}<\mathbf{0 . 0 5})$.

\begin{tabular}{|c|c|c|c|c|c|c|}
\hline & & 100 SW (g) & SW/plant (g) & no. S/plant & L/plant & SDW (g) \\
\hline Variety & $\begin{array}{l}\text { Krassie } \\
\text { Bohoot } 210\end{array}$ & $\begin{array}{l}2.354^{\mathrm{b}} \\
3.929^{\mathrm{a}}\end{array}$ & $\begin{array}{l}2.012^{\mathrm{a}} \\
1.200^{\mathrm{b}}\end{array}$ & $\begin{array}{l}85.825^{\mathrm{a}} \\
35.325^{\mathrm{b}}\end{array}$ & $\begin{array}{l}5.500^{\mathrm{a}} \\
5.250^{\mathrm{a}}\end{array}$ & $\begin{array}{l}2.225^{\mathrm{b}} \\
2.700^{\mathrm{a}}\end{array}$ \\
\hline Treatment & $\begin{array}{l}\text { Control } \\
\text { Salinity } \\
\mathrm{Ki}+\mathrm{K}+\mathrm{S} \\
\mathrm{GA} 3+\mathrm{K}+\mathrm{S}\end{array}$ & $\begin{array}{l}3.575^{\mathrm{a}} \\
2.383^{\mathrm{c}} \\
3.458^{\mathrm{a}} \\
3.150^{\mathrm{b}}\end{array}$ & $\begin{array}{l}2.026^{\mathrm{a}} \\
1.100^{\mathrm{d}} \\
1.800^{\mathrm{b}} \\
1.500^{\mathrm{c}}\end{array}$ & $\begin{array}{l}65.500^{\mathrm{a}} \\
47.000^{\mathrm{b}} \\
64.300^{\mathrm{a}} \\
65.500^{\mathrm{a}}\end{array}$ & $\begin{array}{c}6.500^{\mathrm{a}} \\
4.000^{\mathrm{c}} \\
6.000^{\mathrm{a}} \\
5.000^{\mathrm{bc}}\end{array}$ & $\begin{array}{l}2.850^{\mathrm{a}} \\
2.050^{\mathrm{c}} \\
2.550^{\mathrm{b}} \\
2.400^{\mathrm{b}}\end{array}$ \\
\hline
\end{tabular}

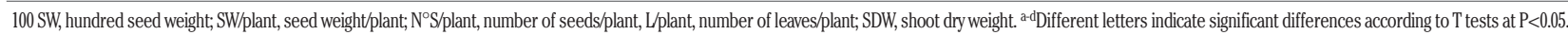

Table 3. Effect of salinity and PGR treatments on some morphological parameters and yield components at maturity of two bread wheat varieties.

\begin{tabular}{llccccc}
\hline & Variety & 100 SW $(\mathrm{g})$ & SW/plant $(\mathrm{g})$ & no. S/plant & W/plant & SDW $(\mathrm{g})$ \\
Control & Krassie & $2.8 \pm 0.05$ & $2.4 \pm 0.26$ & $90.7 \pm 4.23$ & $7.0 \pm 1.00$ & $2.4 \pm 0.10$ \\
& Bohoot 210 & $4.4 \pm 0.26$ & $1.71 \pm 0.05$ & $40.3 \pm 1.10$ & $6.0 \pm 0.00$ & $3.3 \pm 0.22$ \\
$\mathrm{~S}$ & Krassie & $1.7 \pm 0.42$ & $1.4 \pm 0.05$ & $76.3 \pm 1.27$ & $4.0 \pm 1.00$ & $1.9 \pm 0.18$ \\
& Bohoot 210 & $3.1 \pm 0.17$ & $0.8 \pm 0.12$ & $17.7 \pm 1.42$ & $4.0 \pm 1.00$ & $2.2 \pm 0.26$ \\
\hline $\mathrm{Ki}+\mathrm{K}+\mathrm{S}$ & Krassie & $2.7 \pm 0.17$ & $2.2 \pm 0.16$ & $86.3 \pm 1.05$ & $6.0 \pm 0.00$ & $2.3 \pm 0.17$ \\
& Bohoot 210 & $4.3 \pm 0.29$ & $1.4 \pm 0.14$ & $42.3 \pm 3.05$ & $6.0 \pm 1.00$ & $2.8 \pm 0.22$ \\
$\mathrm{GA3}+\mathrm{K}+\mathrm{S}$ & Krassie & $2.3 \pm 0.23$ & $2.1 \pm 0.10$ & $90.0 \pm 1.04$ & $5.0 \pm 0.00$ & $2.3 \pm 0.26$ \\
& Bohoot 210 & $4.0 \pm 0.20$ & $0.9 \pm 0.10$ & $41.0 \pm 1.37$ & $5.0 \pm 1.00$ & $2.5 \pm 0.17$ \\
\hline
\end{tabular}

$100 \mathrm{SW}$, hundred seed weight; SW/plant, seed weight/plant; $\mathrm{N}^{\circ} \mathrm{S} /$ plant, number of seeds/plant, L/plant, number of leaves/plant; SDW, shoot dry weight; S, salinity treatment; Ki+K+S, kinetin + potassium nitrate + salinity, $\mathrm{GA} 3+\mathrm{K}+\mathrm{S}$, giberellic acid + potassium nitrate + salinity; S, salinity; Ki, kinetin; K, potassium nitrate; GA3, giberellic acid; $( \pm)$ standard deviation. 
In cultivar 'Bohoot210', the results of the gene expression of PEPCs indicated that under salt stress conditions, the gene expression increased up to 1.74 -fold while in the salt-stressed plants which sprayed with kinetin + potassium, the gene expression was induced up to 2.73 times, and in the presence of salinity + GA3 + potassium PEPCs increased up to 2.01 times compared to control plants.

For RBCs, the expression patterns analysis in response to salt stress and the two other treatments revealed significant induction in the gene expression level. Salt stress induced an over expression in 'Krassie' cultivar by 2.43 times, and in salt-stressed plants sprayed with kinetin + potassium it was5.6 times compared to control plants; while in salt-stressed plants sprayed with GA3 + potassium, gene expression RBCs increased up to 2.75 times compared to the control (Figure 2). The gene expression of RBCs indicated that under salt-stressed conditions, the gene expression of 'Bohoot 210 ' increased up to 2.01-fold, while, in the salt-stressed plants sprayed with kinetin + potassium, the gene expression induced up to 3.53 times. Finally, the gene expression in the stressed plants that were sprayed with GA3 + potassium was induced up to 2.66 times more than in control plants. We also noted that kinetin induced more PEPCs and RBCs than GA3, and expression was more induced in 'Krassie' than in 'Bohoot 210'.

\section{Discussion}

In Libya, environmental constraints have placed severe limitations on the development of agriculture (FAO, 2019) and have made the supply of seeds more scarce and expensive. In 2014, the Agriculture Research Center in Tripoli selected a new variety 'Bohoot 210' to improve bread wheat production. The present study showed, in the absence of salt stress, that 'Bohoot 210' seems to be more productive. The 100 grains weight was higher despite the small number of grains per plant. The release of this variety was probably aiming high yields in non-limiting conditions. This is unlike the local variety Krassie that had a lower aerial dry mass and a lower 100 grains weight in control conditions, but appears more resistant to salt stress with a lower reduction of $3 / 5$ parameters in the presence of salt stress compared to 'Bohoot 210'. The reduction of all morpho-agronomic parameters under salt stress

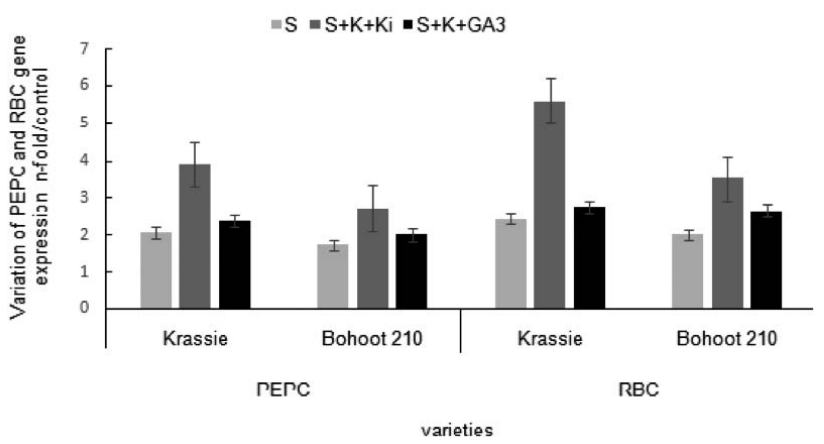

Figure 2. Variation of PEPCs and RBCs gene expression $n$-fold compared to control under salinity and plant growth regulators of the two bread wheat varieties. $\mathrm{Ki}+\mathrm{K}+\mathrm{S}$, kinetin + potassium nitrate + salinity; $\mathrm{GA3}+\mathrm{K}+\mathrm{S}$, giberellic acid + potassium nitrate + salinity; S, salinity; Ki, kinetin; $K$, potassium nitrate; GA3, giberellic acid. varied between -15.8 and $-42.9 \%$ for 'Krassie' and -29.5 and $-56.1 \%$ for 'Bohoot 210 ' According to Julkowska and Testerink (2015), salt stress reduced the water status and leads to growth reduction and limitation of plant productivity.

Among the methods that have been used to counter the negative effects of salinity, PGRs sprayed on plants is considered one promising approach to ensure production and sustainability (Nimir et al., 2015). The current study showed that the level of GB under salt stress was different for the two varieties of wheat and between the two PGR treatments. In fact, the GB content was more important under kinetin than AG3 and more important for the 'Krassie' genotype than for the 'Bohoot 210' genotype under GA3 spraying. Similar results were found for several kinds of cereal genotypes cultivated under salinity (Brunk et al., 1989), which generated osmolytes including proline, glycine betaine, and total soluble sugar (Shelke et al., 2019). The difference in accumulation in GB may be the result of the susceptibility of genotypes to salinity (Mäkelä et al., 2019). The damage induced by salinity is more important in 'Bohoot 210' with a lower GB content as compared to the tolerant variety 'Krassie'. It is well known that GB is an osmoprotectant against abiotic stress (Tian et al., 2017) and plays a role in different processes in plant metabolism and plant development (Kurepin et al., 2015), which might explain the better agronomic performance of the local variety 'Krassie' in the current study.

Plant growth regulator application showed a significant effect on almost all the morphological and agronomic investigated characters. Spraying of gibberellic acid and kinetin significantly increased development and grain yield components of the two bread wheat varieties compared to saline treatment (S). Moreover, the combined application of salinity and PGRs gave better plant growth, development and yield over the control. Therefore, both salinity and PGRs might interact positively to improve plant tolerance. These two PGRs (kinetin and GA3) enhanced plant salt tolerance and induced a lower reduction in all the measured parameters as compared to salinity. Phytohormones regulate plant growth and development (Khan et al., 2016) and provide tolerance to plants under unfavourable conditions (Shahzad et al., 2018; Sharma et al., 2019; Tanveer et al., 2019). It was also noted that kinetin improved the plant salt tolerance higher than GA3 by increasing more GB accumulation, particularly in the case of the 'Krassie' genotype. Thus it could be regarded as an essential regulator in the translocation and partitioning of photoassimilates for gain filling (Khan et al., 2016), which enhanced the water use efficiency (Iqbal and Ashraf, 2013) and increased the development and grain yield in the current study. These results revealed the practical significance of plant growth regulators, including kinetin, to counter the salinity stress in field conditions (Gurmani et al., 2018).

The application of PGRs, particularly the kinetin, on stressed plants enhanced salinity tolerance in both genotypes also by the activation of the expression level of PEPCs and RBCs. We found that kinetin induced more PEPCs and RBCs than GA3and more for 'Krassie' than Bohoot 210'. Cheng et al. (2016) reported that a large number of PEPC genes induced by abiotic stresses play important roles in the regulation of plant tolerance to stress by acting in the cytoplasm of plant cells. This PEPC plays an important role in carbon and nitrogen metabolism of $\mathrm{C} 3$ plants and may explain the morphological and agronomic results recorded in both varieties, in particular the local variety. Therefore, the exogenous application of plant growth regulators to bread wheat under salt stress conditions may overcome their deficiency and improve development, plant growth, and grain yield.

'Krassie', the oldest variety in Libya, is highly productive under salt stress and showed traits of tolerance to salinity. These results are in accordance with the study of Slama et al. (2018) 
which showed that old cultivars of durum wheat are the best-adapted to local conditions. Romdhane et al. (2020) also studied the response of two barley varieties, one old and one new, to water deficit stress and reported that the old variety performed better in terms of yield and tolerance to drought in Tunisia. The study of Atar et al. (2020) showed that the old wheat variety reached the harvest maturity before the new varieties which avoids the high temperature, water and salt stress occurred at the end of the season. Wheat landraces have also long-standing adaptations to local conditions. According to Ammar et al. (2011) the first hybridization effort conducted in Tunisia in the early 1930s involved crosses among local types or between local types and landraces from the Mediterranean regions, they resulted in the release of significant cultivars which were earlier, higher yielding and with better grain quality characteristics.

\section{Conclusions}

In conclusion, we demonstrated that the application of PGR, kinetin, and GA3, enhanced the performance of the two varieties under salinity treatment in comparison with the control. The degree of variation in the studied parameters was considerable between the two varieties and between PGR treatments. Kinetin induced more GB, PEPC, and RBC accumulation than GA3, and the 'Krassie' variety seems to be more salt-tolerant than 'Bohoot 210'. Therefore, kinetin treatment may be recommended as a potential method of improving salt stress resistance by enhancing GB synthesis in bread wheat.

The difference between the old and new bread wheat varieties generated in this research supports the use of the oldest one in the arid and semi-arid zones characterized by a high concentration of salts in the soil and the irrigated water. Because the old variety 'Krassie' seems to be more tolerant than the recent one 'Bohoot 210', conservation of local ecotypes ('Krassie' in Libya) growing under the local agricultural environment could be of great importance to cater to the requirement of local productivity.

\section{Highlights}

- Salt stress reduced plant growth and productivity of bread wheat varieties.

- Growth regulator improved the performance of the morphometric parameters.

- The performance was more effective for kinetin treatment than for gibberellic acid.

- Kinetin improved the glycine betaine gene expression more than gibberellic acid.

- Kinetin increased significantly the phosphoenolpyruvate carboxylase and ribulose biphosphate carboxylase gene expression.

\section{References}

Alsharhan AS, Wood WW, Goudie AS, Fowler A, Abdellatif EM, 2000. Desertification in the ThirdMillennium. In: Routledge.com. 1st Edition (Hardback) - Routledge, Dubai, p 504. Available from: https://www.routledge.com/Desertification-in-the-ThirdMillennium-Proceedings-of-an-International/AlsharhanWood-Goudie-Fowler-Abdellatif/p/book/9789058095718
Ammar K, Gharbi MS, Deghaies M, 2011. Wheat in Tunisia, chapter 18. In: Bonjean AP, Angus WJ, Van Ginkel M (Eds.), The World Wheat Book: A History of Wheat Breeding, Vol 2. TEC. and DOC. Lavoisier, 1193 pp.

Atar B, 2020. Comparison of development of new and old wheat varieties at high temperature conditioning. Turkish JAF Sci. Tech. 8:426-9.

Bayramov S, Guliyev N, 2014. Changes in Rubisco activase gene expression and polypeptide content in Brachypodium distachyon. Plant Physiol. Biochem. 81:61-6.

Bessieres MA, Gibon Y, Lefeuvre JC, Larher F, 1999. A single-step purification for glycine betaine determination in plant extracts by isocratic HPLC. J. Agric. Food Chem. 47:3718-22.

Brunk DG, Rich PJ, Rhodes D, 1989. Genotypic variation for glycinebetaine among public inbreds of maize. Plant Physiol. 91:1122-5.

Buba S, Mohamed ZA, Latif IA, Abdullah AM, Iliyas A, 2017. Analysis of technical efficiency of traditional wheat farming in Fezzan region, Libya. J. Agric. Econ. Rural Develop. 3:251-8.

Cheng G, Wang L, Lan H, 2016. Cloning of PEPC-1 from a C4 halophyte Suaeda aralocaspica without Kranz anatomy and its recombinant enzymatic activity in responses to abiotic stresses. Enzyme Microb. Technol. 83:57-67.

Crespo Herrera LA, Crossa J, Huerta-Espino J, Vargas Hernández M, Mondal S, Velu G, Payne TS, Braun HJ, Singh RP, 2018. Genetic gains for grain yield in CIMMYT's semi-arid wheat yield trials grown in suboptimal environments. Crop Sci. 58:1890-8.

Davies PJ (Ed.), 2010. Plant Hormones: Biosynthesis, Signal Transduction, Action!, 3rd edn. Springer Netherlands. Available

from: https://www.springer.com/gp/book/9781402026843

Doubnerová V, Ryšlavá H, 2011. What can enzymes of $\mathrm{C}_{4}$ photosynthesis do for $\mathrm{C}_{3}$ plants under stress? Plant Sci. Int. J. Exp. Plant Biol. 180:575-83.

FAO, 2019. The impact of the crisis on agriculture.in: Key findings from the 2018 Multi-sector Needs Assessment, CA3099EN/1/04: 1-18.

Gurmani A, Khan S, Ali A, Rubab T, Timothy Schwinghamer T, Ghulam Jilani PAAUR, Abid Farid TU of H, Jinlin Zhang C of PAS and T, 2018. Salicylic acid and kinetin mediated stimulation of salt tolerance in cucumber (Cucumis sativus L.) genotypes varying in salinity tolerance. Hortic. Environ. Biotechnol. Available from: http://agris.fao.org/agrissearch/ search.do?recordID $=$ KR2019002110

Hossain MS, Dietz K-J, 2016. Tuning of redox regulatory mechanisms, reactive oxygen species and redox homeostasis under salinity stress. Front. Plant Sci. 7:548.

Iqbal M, Ashraf M, 2013. Gibberellic acid mediated induction of salt tolerance in wheat plants: Growth, ionic partitioning, photosynthesis, yield and hormonal homeostasis. Available from: https://pubag.nal.usda.gov/catalog/568303

Julkowska MM, Testerink C, 2015. Tuning plant signaling and growth to survive salt. Trends Plant Sci. 20:586-94.

Khan MIR, Asgher M, Khan NA, 2014. Alleviation of salt-induced photosynthesis and growth inhibition by salicylic acid involves glycinebetaine and ethylene in mungbean (Vigna radiata L.). Plant Physiol. Biochem. 80:67-74.

Khan SW, Gurmani AR, Jalaluddin, Qayyum A, Abbasi KS, Liaquat M, Ahmad Z, 2016. Exogenously applied gibberellic acid, indole acetic acid and kinetin as potential regulators of source-sink relationship, physiological and yield attributes in rice (Oryza sativa) genotypes under water deficit conditions. Int. J. Agricult. Biol. 18:135-45.

Kurepin LV, Ivanov AG, Zaman M, Pharis RP, Allakhverdiev SI, 
Hurry V, Hüner NPA, 2015. Stress-related hormones and glycinebetaine interplay in protection of photosynthesis under abiotic stress conditions. Photosynth. Res. 126:221-35.

Lambari N, Mandavia C, Sree Ganesh S, 2018. Curative Effect of Ascorbic Acid and Gibberellic Acid on Wheat (Triticum astivum L.) Metabolism under Salinity Stress. Int. J. Curr. Microbiol. Appl. Sci. 7:522-33.

Maggio A, De Pascale S, Fagnano M, Barbieri G, 2011. Saline agriculture in Mediterranean environments. Ital. J. Agron. 6:7.

Mäkelä PSA, Jokinen K, Himanen K, 2019. Roles of Endogenous Glycinebetaine in Plant Abiotic Stress Responses. In: Hossain MA, Kumar V, Burritt DJ, Fujita M, Mäkelä PSA (Eds.), Osmoprotectant-Mediated Abiotic Stress Tolerance in Plants: Recent Advances and Future Perspectives. Springer International Publishing, Cham, pp 153-73.

Nhemachena C, Kirsten J, 2017. A historical assessment of sources and uses of wheat varietal innovations in South Africa. South Afr. J. Sci. 113:1-8.

Nimir NEA, Lu S, Zhou G, Guo W, Ma B, Wang Y, 2015. Comparative effects of gibberellic acid, kinetin and salicylic acid on emergence, seedling growth and the antioxidant defence system of sweet sorghum (Sorghum bicolor) under salinity and temperature stresses. Crop Pasture Sci. Available from: http://agris.fao.org/agrissearch/search.do?recordID=US201500160016

Radhouane L, 2013. Climate change impacts on North African countries and on some Tunisian economic sectors. J. Agric. Environ. Int. Dev. JAEID 107:101-13.

Rani S, Sharma MK, Kumar N, Neelam, 2019. Impact of salinity and zinc application on growth, physiological and yield traits in wheat. Curr. Sci. 116: 1324-30.

Romdhane L, Dal Ferro N, Slama A, Radhouane L, 2020. Optimizing irrigation and determining the most sensitive development stage to drought in barley (Hordeum vulgare L.) in a semi-arid environment. Acta Bot. Croat. 79 Available from: http://www.abc.botanic.hr/index.php/abc/article/ view/2698

Rout S, Beura S, Khare N, Patra SS, Nayak S, 2017. Effect of seed pre-treatment with different concentrations of gibberellic acid (GA3) on seed germination and seedling growth of Cassia fistula L. J. Med. Plants Stud. 5:135-8.

Shahzad B, Tanveer M, Che Z, Rehman A, Cheema SA, Sharma A, Song H, Rehman SU, Zhaorong D, 2018. Role of 24-epibrassinolide (EBL) in mediating heavy metal and pesticide induced oxidative stress in plants: A review. Ecotoxicol. Environ. Saf. 147:935-44.

Sharma A, Shahzad B, Kumar V, Kohli SK, Sidhu GPS, Bali AS, Handa N, Kapoor D, Bhardwaj R, Zheng B, 2019. Phytohormones Regulate Accumulation of Osmolytes Under Abiotic Stress. Biomolecules 9: pii: E285.

Shelke DB, Nikalje GC, Chambhare MR, Zaware BN, Penna S, Nikam TD, 2019. Na+ and Cl- induce differential physiological, biochemical responses and metabolite modulations in vitro in contrasting salt-tolerant soybean genotypes. 3 Biotech 9:91.

Slama A, Mallek-Maalej E, Ben Mohamed H, Rhim T, Radhouane $\mathrm{L}, 2018$. A return to the genetic heritage of durum wheat to cope with drought heightened by climate change. PLoS One 13:e0196873.

Suo J, Zhao Q, David L, Chen S, Dai S, 2017. Salinity Response in Chloroplasts: Insights from Gene Characterization. Int. J. Mol. Sci. 18: pii: E1011.

Tanveer M, Shahzad B, Sharma A, Khan EA, 2019. 24Epibrassinolide application in plants: An implication for improving drought stress tolerance in plants. Plant Physiol. Biochem. 135:295-303.

Taylor JRN, Schober TJ, Bean SR, 2006. Novel food and non-food uses for sorghum and millets. J. Cereal Sci. 44:252-71.

Tian F, Wang W, Liang C, Wang X, Wang G, Wang W, 2017. Overaccumulation of glycine betaine makes the function of the thylakoid membrane better in wheat under salt stress. Crop J. 5:73-82.

Wani SA, Chand S, Ali T, 2013. Potential Use of Azotobacter Chroococcum in Crop Production: An Overview. Curr. Agric. Res. J. 1:35-8.

Woodrow P, Ciarmiello LF, Annunziata MG, Pacifico S, Iannuzzi F, Mirto A, D'Amelia L, Dell'Aversana E, Piccolella S, Fuggi A, Carillo P, 2017. Durum wheat seedling responses to simultaneous high light and salinity involve a fine reconfiguration of amino acids and carbohydrate metabolism. Physiol. Plant. 159:290-312.

Yadav S, Redden R, Hatfield J, Ebert A, Hunter D, 2019. Food security and climate change. John Wiley. Available from: https://www.bioversityinternational.org/e-library/publications/detail/food-security-and-climate-change/

Zanotti RF, Lopes JC, Motta LB, Freitas AR de, Mengarda LHG, 2013. Tolerance induction to saline stress in papaya seeds treated with potassium nitrate and sildenafil citrate. Semina Ciênc. Agrár. 34:3669. 